\title{
Penentuan Jalur Evakuasi Terpendek Pada Industri Plastik Menggunakan Ant Colony Optimization
}

\author{
Mades Darul Khairansyah*1, Moch Luqman Ashari ${ }^{2}$, Imroatul Mufidah ${ }^{3}$ \\ ${ }^{123}$ Program Studi Teknik Keselamatan dan Kesehatan Kerja \\ Politeknik Perkapalan Negeri Surabaya \\ E-mail: *mades@ppns.ac.id
}

Received 30-04-2021; Reviewed 07-05-2021; Accepted 12-05-2021

Journal Homepage: http://ktj.pktj.ac.id/index.php/ktj

DOI: $10.46447 / k t j . v 8 i 1.312$

\begin{abstract}
Abstrak
Industri plastik memiliki karyawan sebanyak 927 orang yang menempati lahan 12.062 $\mathrm{m}^{2}$. Jam operasional pada industri plastik untuk unit produksi adalah 24 jam non stop. Dengan jumlah dan jadwal tersebut mengkibatkan kepadatan pekerja yang memiliki risiko untuk mengakibatkan kecelakaan. Perusahaan plastik ini memiliki riwayat kecelakaan kerja. Pada perusahaan ini pernah terjadi kebakaran pada unit ABM pada bulan September tahun 2018 dan divisi bengkel pada Mei tahun 2014. Ant Colony Optimization (ACO) sangat cocok menentukan jalur evakuasi dalam penanganan bencana karena algoritma ini melakukan pembaruan pada feromon yang dapat menghasilkan simulasi dengan solusi lebih optimal karena memiliki laju konvergensi yang cepat, sehingga ACO akan digunakan dalam menentukan Jalur evakuasi terpendek pada industri plastik. Pada penelitian ini digunakan feromon awal sebesar 0,0098. Hasil penentuan parameter yang akan digunakan, meliputi number of iterations yaitu 500, number of ant sebesar 100, nilai Alpha sebesar 1 serta Beta sebesar 5 dan evaporation rate sebesar 0.5. Dari hasil optimasi cost yang paling rendah adalah cost 2 sehingga didapatkan rute evakuasi untuk ruang Circullar Loom menuju Koridor 3 dilanjutkan keluar melalui pintu exit 4 sehingga menuju Titik kumpul 1 . Semakin tinggi cost yang dihasilkan maka akan mengakibatkan rute yang dilewati menajadi jauh sehingga meningkatkan waktu evakuasi.
\end{abstract}

Kata kunci: Ant Colony Optimization, Optimization, Jalur Evakuasi

\section{PENDAHULUAN}

Industri plastik memiliki karyawan sebanyak 927 orang yang menempati lahan $12.062 \mathrm{~m}^{2}$. Pada perusahaan ini sendiri pada proses produksi terdapat enam divisi yang terdiri atas divisi ABM (Automatic Bag Machine), perajutan (circular), divisi laminating, divisi packing, divisi peleburan (Extruder) dan divisi Gudang. Jam operasional pada industri plastik untuk unit produksi adalah 24 jam non stop. Dengan jumlah karyawan tersebut, perusahaan membagi jam kerja karyawan menjadi 3 shift kerja dan 4 group untuk unit produksi. Dengan jumlah dan jadwal tersebut mengkibatkan kepadatan pekerja yang memiliki risiko yang dapat mengakibatkan kecelakaan.

Jumlah Kecelakaan di Indonesia berdasarkan data BPJS Ketenagakerjaan pada tahun 2019 berjumlah 182.835 kasus (BPJS Ketenagakerjaan, 2020). Pada 
tahun 2020 sampai bulan Oktober, BPJS Ketenagakerjaan mencatat 129.305 kasus, yang berakibat 4.275 kasus kecacatan, 9 kasus cacat total tetap serta 2002 kasus meninggal dunia. Industri plastik memiliki berbagai macam potensi bahaya untuk meciptakan kasus kecelakaan. Perusahaan plastik ini memiliki riwayat kecelakaan kerja. Pada perusahaan ini pernah terjadi kebakaran pada unit ABM pada bulan September tahun 2018 dan pada divisi bengkel pada mei tahun 2014 juga mengalami hal yang sama. Pada kasus kecelakaan tersebut tidak terdapat korban jiwa, namun mengakibatkan jam operasional yang berkurang dan kerusakan pada mesin yang terbakar.

Dari kasus kecelakaan tersebut, perlu adanya perhatian khusus terhadap jalur evakuasi. Selanjutnya, analisis keselamatan jalan dapat dilakukan sebagai upaya untuk mengetahui penanganan yang tepat (Oktopianto et al., 2021). Jalur evakuasi tersebut meliputi akses jalan keluar, pintu darurat, tempat berkumpul serta penentuan jalur yang dilalui. Pemilihan jalur evakuasi yang tepat dapat mengurangi korban jiwa, karena waktu evakuasi akan semakin cepat dan menghindari aksi saling mendorong dan bertabrakan. Korban jiwa pada saat evakuasi terjadi karena jatuh dan terinjak(Batmetan, 2016). Salah satu cara untuk memilih jalur evakuasi yang tepat adalah dengan menggunakan optimasi. Optimiasi digunakan untuk menetukan menentukan jarak terpendek dari unit produksi, karena semakin cepat dan tepat waktu yang dibutuhkan dalam proses evakuasi akan berpengaruh pada semakin banyaknya jiwa yang dapat terselamatkan (Fuad \& Aryawan, 2011).

Terdapat 2 metode optimasi, metode konvensional dan metode heuristik (Biyanto, Khairansyah, Bayuaji, Firmanto, \& Haksoro, 2015). Contoh optimasi konvensional adalah algoritma algoritma Bellman-Ford dan Floyd-Warshall. Sedangkan contoh metode optimasi heuristic adalah Imperialist Competitive Algorithm (ICA) (Atashpaz-Gargari \& Lucas, 2007), Genetic Algorithm (GA) dan Ant Colony Optimization (ACO) (Dorigo, Maniezzo, \& Colorni, 1996). ACO merupakan salah satu optimasi yang digunakan dalam menentukan jalur. Salah stu pengunaan ACO adalh menentukan jalur terpendek rute pariwisata di Aceh. Dengan menggunakan ACO dapat memperpendek jalur pariwisata menjadi 120,85 Km (Durisman, Ramli, \& Rusdiana, 2017) serta dalam skala sumulasi juga menghasilkan jalur terpendek dengan cepat(Fallo, 2018). Selain itu, ACO juga digunakan dalam jalur distribusi obat di purwokerto. Hal tersebut dilakukan untuk menentukan jalur terpendek sehingga didaptkan jalur terpendek 114,62 km(Risqiyanti, Yasin, \& Santoso, 2019). ACO juga digunakan untuk jalur distribusi sampah(Irsyad, Iskandar, Tiraz, \& Informatika, 2019).

Dalam menentukan jalur evakuasi dalam penanganan bencana, ACO sangat cocok karena algoritma ini melakukan pembaruan pada feromon yang dapat menghasilkan simulasi dengan solusi lebih optimal karena memiliki laju konvergensi yang cepat (Batmetan, 2016). Selain itu ACO juga digunakan dalam menentukan jalur evakuasi tetapi dalam skala simulasi, dari hasil tersebut didapatkan hasil yang lebih cepat(Angelia, Jondri, \& Arifianto, 2015). Dari beberapa keunggulan ACO yang telah dipaparkan maka penelitian ini akan menentukan Jalur evakuas terpendek pada industri plastik menggunakan ACO. 


\section{METODE}

Penelitian ini akan dilakukan menggunakan metode Algoritma Ant Colony Optimization untuk menentukan jalur terpendek secara efektif. ACO merupakan teknik probabilitas yang berfungsi menyelesaikan masalah sesuai dengan tingkah laku semut dalam koloni. Algoritma ini didasarkan pada graf yang akan dimulai dari sebuah starting point, yaitu titik awal, yang kemudian ada node yang diibaratkan titik - titik sebagai representasi dari daerah yang dilalui sampai menuju titik finish yang diinginkan. Secara umum penyelesaian masalah menggunakan metode Algoritma Ant Colony Optimization dapat dilihat pada Gambar 1.

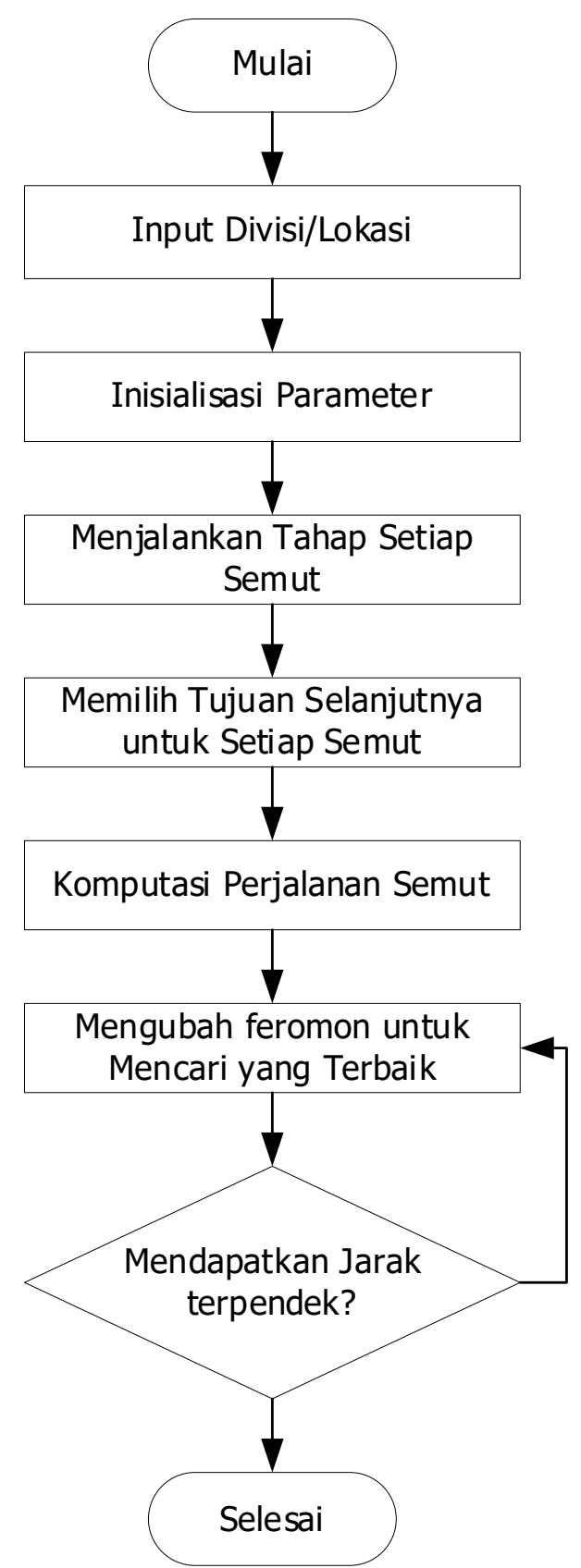

Gambar 1. Algoritma Ant Colony Optimization 


\section{HASIL DAN PEMBAHASAN Hasil}

Pada tahap pencarian rute terpendek untuk menuju Assimbly Point diawali dengan Menginisialisasi harga pada parameter-parameter yang akan digunakan, meliputi: intesitas jejak semut antar titik dan perubahannya $\left(\mathrm{T}_{\mathrm{ij}}\right)$, banyaknya titik (n) termasuk $x$ dan y (koordinat) atau $d_{i j}$ (jarak antar titik), penentuan titik awal dan titik tujuan, tetapan siklus semut (Q), tetapan pengendali intensitas jejak semut $(a)$, tetapan pengendali visibilitas $(\beta)$, visibilitas antar kota $=1 / d_{i j}\left(\eta_{i j}\right)$, jumlah semut, dan jumlah siklus maksimum.

Tahap selanjutnya adalah inisialisasi titik awal pada setiap semut. Sejumlah $\mathrm{m}$ semut ditempatkan pada titik awal yang ditentukan ketika inisialisasi $\mathrm{T}_{\mathrm{ij}}$ selesai dilakukan. Tahap selanjutnya dalam ACO adalah Transisi Status. Pada tahap ini disebut juga dengan tahap pemilihan titik tujuan, sejumlah semut $\mathrm{m}$ yang berada pada titik $\mathrm{m}$ (titik awal) akan memilih jalur untuk menuju titik berikutnya yaitu titik j berdasarkan persamaan (1).

$$
P_{r s}^{k}=\left\{\begin{array}{c}
\frac{\left[\tau_{r u}\right]\left[\eta_{r u}\right]^{\beta}}{\sum u \in J K\left[\tau_{r u}\right]\left[\eta_{r u}\right]^{\beta}} \\
0
\end{array}\right.
$$

Pada tahapan selanjutnya adalah pembaruan feromon lokal yang digunakan semut untuk membangun sebuah solusi dengan menggunakan persamaan (2). Pebaruan feromon global pada semut, langkah ini dilakukan hanya pada lintasan jalur terbaik. Jumlah feromon T_rs akan diubah sesuai persamaan (3) dan (4). Ketika semua proses sudah dilakukan maka akan didapatkan jarak terpendek untuk menuju titik tujuan.

$$
\begin{aligned}
\tau_{r s} & =(1-\rho) \cdot \tau_{r s}+\rho \cdot \Delta \tau_{r s} \\
\tau_{r s} & =(1-\alpha) \cdot \tau_{r s}+\alpha \cdot \Delta \tau_{r s} \\
\tau_{r s} & =\left(\begin{array}{c}
L_{g b} \\
0
\end{array}\right)^{-1} \quad \begin{array}{l}
\text { jika sebaliknya } \\
\text { sebalikna }
\end{array}
\end{aligned}
$$

Memilih rute terpendek menuju titik kumpul dapat membantu mempermudah proses evakuasi yang tengah dilakukan. Perhitungan jarak terpendek menuju titik kumpul saat terjadi kebakaran menggunakan metode Ant colony optimization. Proses perhitungan jarak dilakukan pada setiap persimpangan yang ditemui saat menuju titik kumpul. Penentuan titik koordinat dan skala yang akan dipakai pada layout perusahaan. Skala yang digunakan dalam penelitian ini yaitu dalam satuan pixel. Penelitian ini dilakukan pada 5 divisi produksi yang terdiri dari Divisi Extruder, Divisi Jumbo Bag, Divisi AD Star, Divisi Circullar Loom, Divisi Circullar Loom 2 dan Divisi ABM. Penentuan titik start dari masing-masing divisi digunakan satu titik perwakilan tempat yang selalu terdapat pekerja dari masing-masing divisi menuju titik kumpul.

Dalam menyelesaikan kasus rute terpendek dari masing-masing divisi bagian produksi industri plastik menggunakan metode ACO perlu ditentukan terlebih dahulu koordinat-koordinat yang menjadi kemungkinan jalur yang dillewati oleh semut. Untuk koordinat dari divisi Circullar dapat dilihat pada tabel 1 berikut : 
Tabel 1. Koordinat Divisi Circullar Menuju Titik kumpul 1

\begin{tabular}{cccc}
\hline Inisial & Nama Tempat & $\begin{array}{c}\text { Koordinat } \\
\text { Latitude }\end{array}$ & $\begin{array}{c}\text { Koordinat } \\
\text { Longitude }\end{array}$ \\
\hline N1 & Ruang Circullar Loom & 1550 & 770 \\
N2 & Ruang Circullar Loom & 750 & 770 \\
N3 & Koridor 3 & 550 & 770 \\
N4 & Depan Kantor & 300 & 770 \\
N5 & Titik kumpul 1 & 300 & 510 \\
\hline
\end{tabular}

Sumber : Hasil Pengukuran, 2021

Titik titik koordinat tersebut diambil dari layout perusahaan sehingga menghasilkan koordinat yang akurat sesuai dengan kondisi perusahaan. Untuk perhitungan jarak antar titik dihitung menggunakan persamaan (5). Sementara untuk hasil perhitungan jarak dari antar masing-masing koordinat dapat dilihat pada tabel 2.

$$
\begin{aligned}
\mathrm{D}_{(\mathrm{i}, \mathrm{j})} & =\sqrt{\left((X(i)-X(j))^{2}+(Y(i)-Y(j))^{2}\right)} \\
\mathrm{N}_{(1,2)} & =\sqrt{(1550-750)^{2}+(770-770)^{2}} \\
& =\sqrt{800^{2}+0^{2}} \\
& =800
\end{aligned}
$$

Tabel 2. Jarak Divisi Circullar Menuju Titik kumpul 1

\begin{tabular}{cccccc}
\hline Jarak & N1 & N2 & N3 & N4 & N5 \\
\hline N1 & 0 & 800 & 1000 & 1250 & 1276,75 \\
N2 & 800 & 0 & 200 & 450 & 519,71 \\
N3 & 1000 & 200 & 0 & 250 & 360,69 \\
N4 & 1250 & 450 & 250 & 0 & 260 \\
N5 & 1276,75 & 519,71 & 360,69 & 260 & 0 \\
\hline
\end{tabular}

Sumber : Hasil Pengujian, 2021

Pada proses perhitungan rute evakuasi dari divisi Circullar menuju Titik kumpul 1, terdapat tiga karakteristik utama dari AOC yaitu tahap transisi status (tahap pemilihan titik yang dituju). Pada tahap ini karyawan yang berada pada divisi $r$ akan memilih untuk menuju ke tempat selanjutnya s. untuk melakukan perhitungan transisi terlebih dahulu dilakukan perhitungan invers jarak sesuai tabel 3.

Tabel 3. Invers Jarak Koordinat dari Divisi Circullar Menuju Titik kumpul 1

\begin{tabular}{cccccc}
\hline Jarak & $\mathrm{N} 1$ & $\mathrm{~N} 2$ & $\mathrm{~N} 3$ & $\mathrm{~N} 4$ & $\mathrm{~N} 5$ \\
\hline $\mathrm{N} 1$ & 0 & 0,00125 & 0,001 & 0,0008 & 0,000783 \\
N2 & 0,00125 & 0 & 0,005 & 0,00222 & 0,001924 \\
N3 & 0,001 & 0,005 & 0 & 0,004 & 0,002772 \\
N4 & 0,0008 & 0,00222 & 0,004 & 0 & 0,003846 \\
N5 & 0,000783 & 0,001924 & 0,002772 & 0,003846 & 0 \\
\hline
\end{tabular}

Sumber : Hasil Pengujian, 2021

Langkah selanjutnya yaitu menetapkan feromon awal, pada penelitian ini digunakan feromon awal ( $\mathrm{T}_{0}$ ) sebesar 0,0098. Penetapan ini berfungsi agar 
setiap ruas memiliki ketertarikan untuk dikunjungi oleh tiap-tiap semut (pekerja). Kemudian pemilihan titik yang akan dituju mempunyai nilai penetapan $\beta=$ 5.Tahap selanjutnya yaitu melakukan perhitungan temporary yang digunakan untuk menenetukan titik-titik yang akan dituju berdasarkan persamaan (6). temporary $(r, s)=\left(\left(T_{r s}\right)\left(\eta_{r s}\right)^{\beta}\right)$

Tabel 4. Nilai Temporary

\begin{tabular}{cccccc}
\hline Jarak & $\mathrm{N} 1$ & $\mathrm{~N} 2$ & $\mathrm{~N} 3$ & $\mathrm{~N} 4$ & $\mathrm{~N} 5$ \\
\hline N1 & 0 & 0,00299 & 0,00098 & 0,000321 & 0,000289 \\
N2 & 0,00299 & 0 & 3,0625 & 0,0531084 & 0,0258 \\
N3 & 0,00098 & 3,0625 & 0 & 1 & 0,161 \\
N4 & 0,000321 & 0,0531084 & 1 & 0 & 0,825 \\
N5 & 0,000289 & 0,0258473 & 0,161 & 0,825 & 0 \\
\hline
\end{tabular}

Sumber : Hasil Pengujian, 2021

Untuk memilih persamaan yang tepat sebagai acuan dalam pemilihan lokasi selanjutnya perlu dibangkitkan suatu bilangan random (q) yang mempunyai nilai 0 sampai 1 serta menetapkan suatu bilangan pembatas $\left(q_{0}\right)$ antara 0 sampai 1 . Pada penelitian ini nilai $\mathrm{q}_{0}$ yang digunakan yaitu sebesar 0,9 sedangkan nilai $\mathrm{q}$ atau nilai random yang dibangkitkan sebesar 0,1 . Hal ini menunjukkan arti bahwa semut saat melakukan proses pencarian jarak terpendek melakukan proses ekploitasi dengan probabilitas $90 \%$ dan proses eksplorasi $10 \%$. Sehingga jalur terpendek yang dipilih yaitu jalur yang memiliki nilai feromon terkuat. Adapun rute yang terbentuk berdasarkan temporary dapat dilihat pada tabel 5 .

Tabel 5. Rute Karyawan yang Terbentuk

\begin{tabular}{|c|c|c|}
\hline karyawan & Rute & Cost \\
\hline P1 & {$\left[\begin{array}{lllll}1 & 4 & 3 & 2 & 5\end{array}\right]$} & 3496 \\
\hline P2 & {$\left[\begin{array}{lllll}1 & 2 & 3 & 4 & 5\end{array}\right]$} & 2787 \\
\hline P3 & {$\left[\begin{array}{lllll}1 & 2 & 4 & 3 & 5\end{array}\right]$} & 3137 \\
\hline
\end{tabular}

Sumber : Hasil Analisis, 2021

Setelah semua karyawan berpindah ke tempat tujuan, maka langkah selanjutnya yaitu melakukan pembaruan feromon lokal. Dalam memperbarui feromon lokal dibutuhkan suatu parameter $\rho$ yang memiliki nilai antara 0 sampai 1. Pada penelitian ini nilai $\rho$ ditetapkan dengan nilai sebesar 0,5 . Untuk menghitung pembaruan feromon lokal $\Delta \mathrm{T}_{1,2}$ sesuai persamaan (7). Hasil pembaharuan feromon dapat dilihat pada tabel 6 .

$$
\Delta \tau_{\mathrm{r}, \mathrm{s}}=\frac{1}{L_{n n} \times c}
$$

Tabel 6. Hasil Pembaruan Feromon Lokal

\begin{tabular}{cccccc}
\hline Jarak & $\mathrm{N} 1$ & $\mathrm{~N} 2$ & $\mathrm{~N} 3$ & $\mathrm{~N} 4$ & $\mathrm{~N} 5$ \\
\hline $\mathrm{N} 1$ & 0,0049 & 0,005025 & 0,005 & 0,00498 & 0,004978 \\
N2 & 0,005025 & 0,0049 & 0,0054 & 0,005122 & 0,005092 \\
N3 & 0,005 & 0,0054 & 0,0049 & 0,0053 & 0,005177 \\
N4 & 0,00498 & 0,005122 & 0,0053 & 0,0049 & 0,005285 \\
N5 & 0,004978 & 0,005092 & 0,005177 & 0,005285 & 0,0049 \\
\hline
\end{tabular}

Sumber : Hasil Analisis, 2021 
Setelah tujuan menuju Titik kumpulyang telah dikunjungi mengalami pembaharuan feromon lokal, maka tahap selanjutnya yaitu melakukan pembarharuan feromon global. Rute yang dapat dilakukan pembaharuan feromon global hanyalah rute dengan hasil jarak terpendek saja. perhitungan pembaharuan feromon global yang menjadi nilai feromon akhir seperti pada persamaan (4) untuk yang belum mencapai terpendek menggunakan persamaan (3). Hasil keseluruhan pembaharuan feromon lokal dapat dilihat pada tabel 7.

Tabel 7. Hasil Pembaruan Feromon Lokal

\begin{tabular}{cccccc}
\hline & $\mathrm{N} 1$ & $\mathrm{~N} 2$ & $\mathrm{~N} 3$ & $\mathrm{~N} 4$ & $\mathrm{~N} 5$ \\
\hline N1 & 0,0049 & 0,005025 & 0,005 & 0,00498 & 0,004978 \\
N2 & 0,005025 & 0,0049 & 0,0054 & 0,005122 & 0,005092 \\
N3 & 0,005 & 0,0054 & 0,0049 & 0,0053 & 0,005177 \\
N4 & 0,00498 & 0,005122 & 0,0053 & 0,0049 & 0,005285 \\
N5 & 0,004978 & 0,005092 & 0,005177 & 0,005285 & 0,0049 \\
\hline
\end{tabular}

Sumber : Hasil Analisis, 2021

\section{Pembahasan}

Hasil penentuan parametet-parameter yang akan digunakan, meliputi: number of iterations yaitu 500 karena dengan perulangan tersebut didapatkan best cost yang menunjukkan hasil paling optimal. Number of ant yang digunakan sebesar 100 semut yang menjadi simbol sebagai jumlah karyawan pada masingmasing divisi agar dicapai bermacam-macam kemungkinan, karena ketika memakai nilai sesuai orang yang berada pada divisi tersebut jalur hasil pemilihan kurang bervariatif. Nilai Alpha pada penelitian ini digunakan nilai sebesar 1 serta Beta dengan nilai sebesar 5 dan evaporation rate sebesar 0.5.

Setelah semua tahap telah diselesaikan, maka dapat disimpulakn bahwa jarak terpendek menuju Titik kumpul 1 yang dilakukan dari divisi Circullar dengan menggunakan algoritma ant colony optimization yaitu dengan membutuhkan cost sebesar 2787 Sedangkan jalur yang dilewati yaitu : ruang Circullar Loom $\rightarrow$ Koridor $3 \rightarrow$ keluar melalui pintu exit $4 \rightarrow$ Titik kumpul 1 . Sedangkan untuk jalur yang lain dapat sesuai tabel 8 . Simulasi jalur evakuasi secara keseluruhan dapat dilihat pada Gambar 2.

Tabel 8. Hasil Pembaruan Feromon Lokal

\begin{tabular}{ccc}
\hline $\mathbf{N}$ & Nama Ruangan & Skema Jalur Keluar \\
$\mathbf{0}$ & & Extruder $\rightarrow$ Exit $7 \rightarrow$ Titik Kumpul 2 \\
\hline 1 & Divisi Extruder & Jahit jumbo Bag $\rightarrow$ Cleaning Room $\rightarrow$ Gudang barang \\
2 & Divisi Jumbo Bag & setengah jadi $\rightarrow$ Exit $5 \rightarrow$ Titik Kumpul 1 \\
& & AD Stakon $\rightarrow$ Exit $6 \rightarrow$ Titik Kumpul 3 \\
3 & Divisi Ad Star & Circullar Loom $\rightarrow$ Starex $\rightarrow$ Titik Kumpul 1 \\
4 & Divisi Circullar Loom 1 & Circullar Loom $\rightarrow$ AD Starkon $\rightarrow$ Exit $6 \rightarrow$ Titik Kumpul 3 \\
5 & Divisi Circullar Loom 2 & ABM $\rightarrow$ Exit $1 \rightarrow$ Tititk Kumpul 1 \\
6 & Divisi ABM &
\end{tabular}

Sumber : Hasil Analisis, 2021 


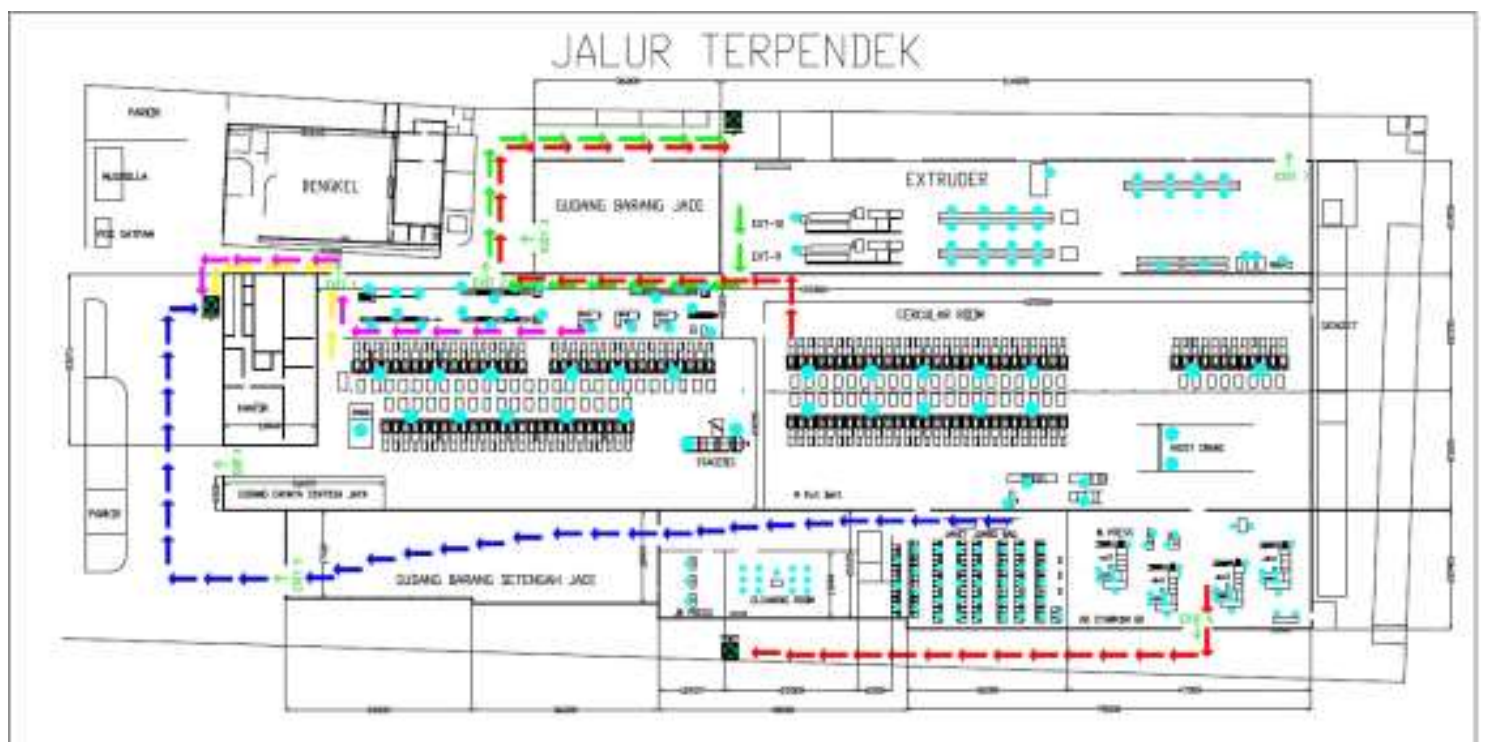

Gambar 2. Layout Rute Keluar Masing-masing Divisi dan Letak karyawan Pada Masing-Masing Divisi

\section{SIMPULAN}

Berdasarkan uraian diatas, penentuan rute evakasi terpendek dilakukan dengan menggunakan metode Ant Colony Optimization untuk mendapatkan jarak terpendek dengan melihat 3 cost paling kecil dari pejalanan yang dilakukan oleh semut. Penggunaan Ant Colony Optimization membantu penentuan jalur evakuasi terpendek sangat cepat disbanding dengan menggunakan metode konvensional. Dari masing masing rute 3 cost terpendek sebelumnya sebagai pertimbangan pemilihan jalur evakuasi yang efektif didapatkan rute pada cost kedua yang terpendek. Dari hasil optimasi cost yang paling rendah adalah cost 2 sehingga didapatkan rute evakuasi untuk ruang Circullar Loom $\rightarrow$ Koridor $3 \rightarrow$ keluar melalui pintu exit $4 \rightarrow$ Titik kumpul 1 . Semakin tinggi cost yang dihasilkan maka akan mengakibatkan rute yang dilewati menajadi sangat jauh sehingga meningkatkan waktu evakuasi. Dalam penelitian ini terdapat beberapa saran untuk peningkatan hasil yang lebih optimal dengan cara menambahan jumlah iterasi yang lebih banyak serta melanjutkan perhitungan waktu evakuasi yang dibutuhkan untuk mecapai titik kumpul. Selain itu juga dapat menggunakan metode heuristic lainnya sebagai pembanding.

\section{DAFTAR PUSTAKA}

Angelia, F. A. I., Jondri, \& Arifianto, A. (2015). Pemilihan Jalur Evakuasi Dalam Keadaan Darurat Menggunakan Algoritma Quantum Ant-Colony Path Selection In Emergency Evacuation Using Quantum Ant- Colony Algorithm, 2(1), 1339-1346.

Atashpaz-Gargari, E., \& Lucas, C. (2007). Imperialist competitive algorithm: An algorithm for optimization inspired by imperialistic competition. 2007 IEEE Congress on Evolutionary Computation, CEC 2007, 4661-4667.

Batmetan, J. R. (2016). Algoritma Ant Colony Optimization ( ACO ) untuk Pemilihan Jalur Tercepat Evakuasi Bencana Gunung Lokon Sulawesi Utara. Jurnal Teknologi Informasi-Aiti, 14(1), 31-48. 
Biyanto, T. R., Khairansyah, M. D., Bayuaji, R., Firmanto, H., \& Haksoro, T. (2015). Imperialist Competitive Algorithm (ICA) for Heat Exchanger Network (HEN) Cleaning Schedule Optimization. In Procedia Computer Science. http://doi.org/10.1016/j.procs.2015.12.099

BPJS Ketenagakerjaan. (2020). Pertumbuhan Agresif untuk Perlindungan Berkelanjutan, $332 . \quad$ Retrieved from https://www.bpjsketenagakerjaan.go.id//assets/uploads/laporan_tahunan/ BPJS_2020_LO17.pdf

Dorigo, M., Maniezzo, V., \& Colorni, A. (1996). Ant system: Optimization by a colony of cooperating agents. IEEE Transactions on Systems, Man, and Cybernetics, Part B: Cybernetics, 26(1), 29-41. http://doi.org/10.1109/3477.484436

Durisman, D., Ramli, M., \& Rusdiana, S. (2017). Designing Application of Ant Colony System Algorithm for the Shortest Route of Banda Aceh City and Aceh Besar Regency Tourism By Using Graphical User Interface Matlab. Jurnal Natural, 172), 83. http://doi.org/10.24815/jn.v0i0.7920

Fallo, D. Y. (2018). Pencarian Jalur Terpendek Menggunakan Algoritma Ant Colony Optimization. Jurnal Pendidikan Teknologi Informasi (JUKANTI), 1(1), 28-32. http://doi.org/10.37792/jukanti.v1i1.8

Fuad, C., \& Aryawan, W. D. (2011). Studi Perencanaan Model Evakuasi Sederhana. Jurnal Teknik POMITS.

Irsyad, M., Iskandar, I., Tiraz, F. F., \& Informatika, T. (2019). Optimasi Jalur Pengangkutan Sampah Menggunakan Metode Ant Colony Optimization Di Kota Pekanbaru. Jurnal CoreIT: Jurnal Hasil Penelitian IImu Komputer Dan Teknologi Informasi, 5(1), 1-7. Retrieved from http://ejournal.uinsuska.ac.id/index.php/coreit/article/view/8196

Oktopianto, Y., Shofiah, S., Rokhman, F. A., \& Pangestu, K. (2021). Analisis Daerah Rawan Kecelakaan ( Black Site ) Dan Titik Rawan Kecelakaan ( Black Spot ) Provinsi Lampung. Borneo Engineering: Jurnal Teknik Sipil, 5(1), 4051. https://doi.org/10.35334/be.v5i1.1777

Risqiyanti, V., Yasin, H., \& Santoso, R. (2019). Pencarian Jalur Terpendek Menggunakan Metode Algoritma "Ant Colony Optimization" Pada GUI Matlab (Studi Kasus: PT Distriversa Buana Mas cabang Purwokerto). Jurnal Gaussian, 8(2), 272-284. http://doi.org/10.14710/j.gauss.v8i2.26671 